\title{
Investigation on up-flow anaerobic sludge fixed film (UASFF) reactor for treating low-strength bilge water of Caspian Sea ships
}

\author{
Seyyed Mohammad Emadian ${ }^{1}$, Mostafa Rahimnejad ${ }^{2 *}$, Morteza Hosseini ${ }^{2}$ and Behnam Khoshandam
}

\begin{abstract}
Background: In order to meet the International Maritime Organization (IMO) objectives, the main purpose of this study was using the cheap and practical wastewater treatment system for low-strength bilge water of Caspian Sea ships; therefore, the low-strength bilge water of the Caspian Sea ships has been treated by up-flow anaerobic sludge fixed film (UASFF) reactor at the ambient temperature.

Results: The reactor operated at two hydraulic retention times (HRTs) of $10 \mathrm{~h}$ and $8 \mathrm{~h}$. The organic loading rates (OLR) ranged (0.12-0.6) $\mathrm{g}$ chemical oxygen demand (COD)/l.day. At the beginning of the experimental procedure, the sludge was immobilized on the surface of the support materials. After 10 days of batch feeding of the reactor with the wastewater as an acclimation period (with COD removal of 59\%), the reactor operated continuously. At the end of the experiment, with the HRT of $8 \mathrm{~h}$ and OLR of $0.6 \mathrm{~g} C O D /$. .day, the COD and total suspended solid (TSS) removal efficiencies reached the amounts of $75 \%$ and $99 \%$, respectively. In addition to the good features of the reactor in removing COD and TSS, the effluent oil concentration was significantly lower than the standard value (15 ppm) which has been laid down for the discharge of the bilge water from ships by the IMO.
\end{abstract}

Conclusions: The obtained data demonstrated that UASFF reactor is an appropriate system for treatment of a low-strength bilge water.

Keywords: Anaerobic treatment, UASFF reactor, COD, pH, TSS, Oil content

\section{Background}

Three kinds of wastewater exist which are produced on ships: black water, grey water and bilge water. Bilge water is the mixture of water, oily fluids, lubricants, cleaning fluids and other similar wastes that accumulate in the lowest part of a ship. The International Maritime Organization (IMO) regulations necessitate that any oil and oil residue discharged in wastewater streams must contain less than $15 \mathrm{mg} / \mathrm{l}$ of oil [1]. The common technology is used in ships for treating bilge water is oil water separator (OWS) using the buoyancy difference of oil and water for separation. Cleaning agents in bilge water can create an emulsion of oil in water. When emulsification takes place, buoyancy difference of oil and

\footnotetext{
* Correspondence: rahimnejad@nit.ac.ir

${ }^{2}$ Department of Chemical Engineering, Babol University of Technology, Babol, Iran

Full list of author information is available at the end of the article
}

water is too small to be treated properly via the existing OWS technology.

Other techniques have been studied in order to treat bilge water including membrane technology $[2,3]$, electrocoagulation [4,5], UF/photocatalytic oxidation [6]. Some disadvantages were reported associated with the application of membrane in treatment of bilge water such as: their relatively high cost of production because of the expensive raw materials, fouling which has a number of negative effects such as the reduction in membrane flux, additional capital and maintenance cost due to membrane replacement and regeneration [2,7]. Karakulski et al. reported a promising usage of laboratoryscale ultrafiltration pilot plant with tubular membranes for the treatment of bilge water. However, the use of additional photocatalytic oxidation stage was necessary to eliminate the residual oil [6]. Rincon et al. concluded that the electrocoagulation process was an effective method in destabilization of oil in water emulsions and 
removing of heavy metals. However, the electricity consumption and the use of additional flotation method should be considered for improving the treatment efficiency [5].

Anaerobic treatment is a well-established technology for treatment of wastes and wastewaters because it is technologically simple for low energy consumption and it is an efficient, economical and environmentally-friendly method. The final product of anaerobic digestion is biogas which is a mixture of methane and carbon dioxide. These produced components can be applied for heating and upgrading natural gas quality or co-generation [8]. One of the most notable developments in anaerobic treatment process technology is the up-flow anaerobic sludge blanket (UASB) reactor. The UASB reactor has some positive features, such as short hydraulic retention time that allows high organic loadings. Furthermore, it has a low energy demand and area requirement $[9,10]$. A major problem of UASB reactor is the long period (several months) required for the formation of granule sludge in the reactor [11]. Although formation of granule in UASB reactors has some advantages, successful treatment of wastewaters with flocculent sludge UASB reactors have been reported [12,13]. The up-flow anaerobic sludge fixed film (UASFF) reactor configuration has combined the advantages of both UASB and Up-flow anaerobic fixed film (UAFF) reactors. This kind of reactor is efficient in the treatment of dilute to high strength wastewaters at low to high Organic Loading Rates $[14,15]$. The packing medium in the hybrid reactor plays an important role in giving a better performance to the UASB reactor such as increasing solids retention by dampening short circuiting, improving gas/liquid/solid separation, and providing surface for biomass attachment.

Bilge water is classified as the low strength group of wastewater [14]. Although anaerobic process is used for the treatment of medium and high strength wastewaters, it has already been applied successfully for a number of waste streams including low strength wastewaters [16-18].

In this study, the efficiency of UASFF reactor (on the basis of COD, TSS, oil removal and biogas production) has been studied in treatment of low-strength bilge water under different low organic loading rates at the ambient temperature.

\section{Methods}

\section{Experimental system}

The schematic diagram of the laboratory-scale UASFF reactor used in this study is presented in Figure 1. The fabricated Plexiglas bioreactor column had an internal diameter of $4.4 \mathrm{~cm}$ and a liquid height of $194 \mathrm{~cm}$. The column consisted of three sections including bottom, middle and top. The bottom part of the column, with a volume of $1823 \mathrm{ml}$ operated as a UASB reactor whereas the middle part of the column with a volume of $855 \mathrm{ml}$ was used as a fixed film reactor. The top part of the bioreactor with a volume of $273 \mathrm{ml}$ was an unpacked column prior to the effluent overflow. The fixed film section of the column was randomly packed with 270 billowy pieces of PVC rings with diameter of $15 \mathrm{~mm}$ and the height of $13 \mathrm{~mm}$ $\left(150 \mathrm{~m}^{2} / \mathrm{m}^{3}\right.$ specific surface areas for each one). The media in the reactor were stabled by using a plastic mesh. The wastewater as a substrate was continuously fed to the

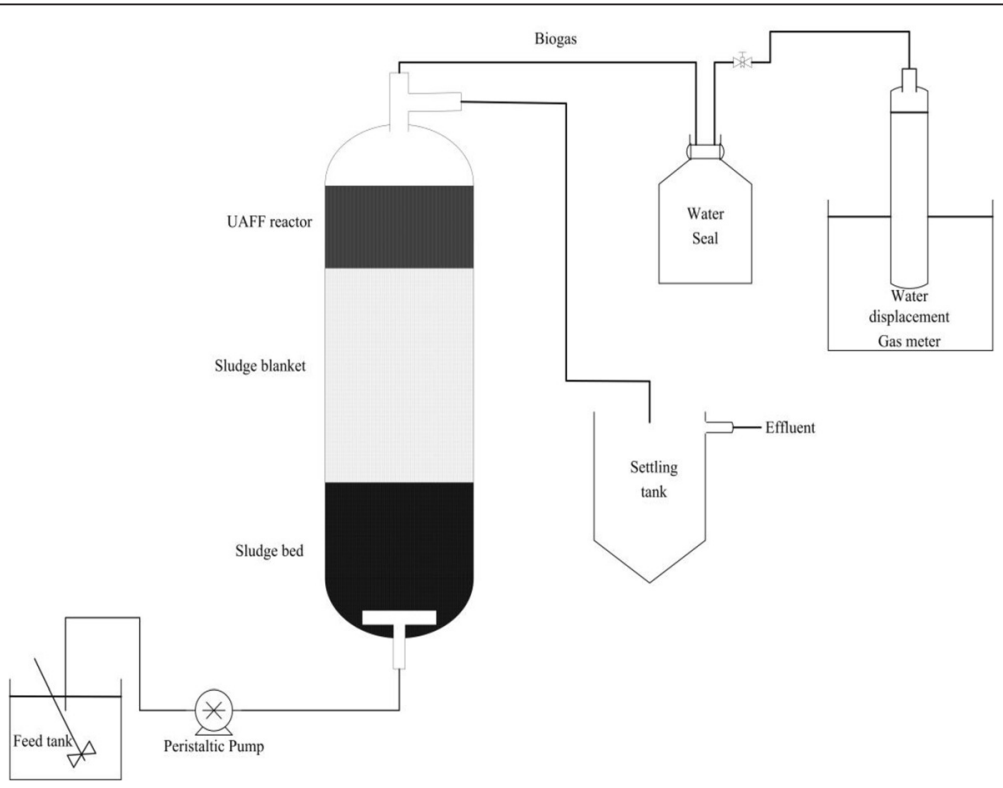

Figure 1 Schematic diagram of the used experimental setup in this research. 
base of the reactor, under the bed of active sludge, through a T-inlet connected to a peristaltic pump. An outlet was provided at the top of the reactor that was connected to a 1 liter funnel shaped settling compartment served as a sedimentation part where the final effluent was collected from the top of this tank. The effluent tube was connected to a gas tank for gas collection by water displacement whenever wanted to measure the produced biogas volume. The reactor operated at ambient temperature $(15-25)^{\circ} \mathrm{C}$.

\section{Wastewater characteristics}

The bilge water was collected from a tank with which anchored cargo ships typically discharged their bilge water to it at Amirabad port, Behshahr, Mazandaran, Iran. The samples were collected from the top, middle and the bottom of the tank in order to provide a uniform sample from all parts of the tank. The UASFF reactor was fed with bilge water pre-settled for $10 \mathrm{~min}$. the characteristics of pre-settled bilge water are summarized in Table. 1. The $\mathrm{pH}$ of the feed was adjusted to 6.8 to 7.2 by adding diluted $\mathrm{HCl}$. The only supplementary nutrient, $\mathrm{MgNO}_{3}$ as a nitrogen supply, was added to yield a COD: $\mathrm{N}$ ratio of 250:5.

\section{Inoculum (seed sludge)}

The reactor was seeded with a mixture of activated sludge from the aerobic wastewater treatment of the Mazandaran pulp and paper industry and a non-granular sludge obtained from an up-flow anaerobic sludge blanket reactor operating with cheese whey wastewater from the Gela food industry of Amol, Mazandaran, Iran. The TSS of the mixture was $13 \mathrm{~g} / \mathrm{l}$. The non-granular sludge was methanogenically active as the biogas bubbles were apparently observed stripping from the sample surface which was collected in a closed bottle.

\section{Analytical methods}

Several monitoring parameters were evaluated during the entire operation, including COD, TSS and oil concentrations, as well as $\mathrm{pH}$, temperature and biogas production volume rate. For COD analysis, HACH's Method 8000, a combination of reactor digestion method and colorimetric method, was used [19]. This method is equivalent to

Table 1 characteristics of pre-settled bilge water; TN and TP were measured in COD $=\mathbf{5 0} \mathbf{~ m g / l}$

\begin{tabular}{ll}
\hline Parameter & Value \\
\hline PH & $8-9$ \\
COD $(\mathrm{mg} / \mathrm{l})$ & $20-200$ \\
$\mathrm{TS}(\mathrm{mg} / \mathrm{l})$ & $800-2400$ \\
$\mathrm{TSS}(\mathrm{mg} / \mathrm{l})$ & $220-1760$ \\
$\mathrm{TN}(\mu \mathrm{g} / \mathrm{l})$ & 836 \\
$\mathrm{TP}(\mu \mathrm{g} / \mathrm{l})$ & 211 \\
\hline
\end{tabular}

standard method 5220D: closed reflux, colorimetric method [20]. Analytical determination of TSS was carried out in agreement with the standard methods for the examination of water and wastewater [20]. Analysis of oil was determined according to USEPA Method 1664, N-Hexane gravimetric method. Temperature and $\mathrm{pH}$ were measured using a $\mathrm{pH} /$ temperature probe (HANNA, PH212, Germany) with automatic temperature compensation. The method used in $\mathrm{pH}$ measurement was generally in compliance with standard method 4500B [20]. Biogas was collected by water displacement and the volume was read from a calibrated gas collection cylinder.

\section{Start-up and operation scheme}

Start-up period usually takes a long time. In order to decrease this time, the immobilization of biomass on the support material was done. So, the mentioned mixture of sludge was used by means of a technique described by Zaiat et al. [21]. The support material in combination with the sludge was stored in $1.5 \mathrm{l}$ closed bottle and homogenized for the period of a week by using a shaker so as to secure steadier immobilization of bio-particles in the supporting material. It is noticeable that this initial immobilization of biomass in the support materials has never been done by the other authors. After this stage, the packing material was filled in its place in the UASFF reactor.

The reactor was inoculated with $500 \mathrm{ml}$ of the same sludge mixture. In order to acclimatize the sludge with bilge water, the reactor was daily batch feed with the bilge water $(50 \mathrm{mg} / \mathrm{l})$ for 10 days. After each feed, the liquid content of the reactor was continuously circulated for 1 day (until the next feed). The acclimation period permitted oxygen level decrease to prevent inhibition of anaerobic bacteria as well as the bacteria population to adjust with the feed wastewater. The TSS concentration of the sludge after the 10-day batch-fed period was $16.5 \mathrm{~g} / \mathrm{l}$. A COD removal of about $59 \%$ was achieved at the end of this acclimation period.

The purpose of the start-up of anaerobic bioreactors is to grow, build up and retain a sufficient concentration of active and well balanced biomass. The start-up was carried out by using stepped organic loading to produce the most rapid biomass development. The start-up stage of the process was began by continuous feeding of the reactor with an initial influent COD concentration of $50 \mathrm{mg} / \mathrm{l}$, HRT of $10 \mathrm{~h}$ and consequently organic loading rate of $0.12 \mathrm{~g} \mathrm{COD} / \mathrm{l}$ day which is remarkably a low value. This influent COD concentration was applied for 21 days. After that, it is increased to $100 \mathrm{mg} / \mathrm{l}$ from the day of 21 to 49 . The HRT of $10 \mathrm{~h}$ was kept constant throughout the startup duration. The reactor was allowed to reach steady state condition before each OLR change. When effluent COD reached a relatively constant value, the steady state 
condition was achieved and then influent OLR can be raised [22]. The experimental procedure is illustrated in Figure 2.

During the experiment, COD reduction, $\mathrm{pH}$ and biogas production were monitored daily. The TSS reduction was usually measured every other day. Also oil reduction was checked 2 times throughout the experiment. The first check was after the end of the start-up period and the second check was after the completion of the whole experiment.

\section{Results and discussion \\ Bioreactor start-up \\ $\mathrm{pH}$}

Changes in acidity $(\mathrm{pH})$ of the effluent from the UASFF reactor during the start-up stage is shown in Figure 3. The $\mathrm{pH}$ was comparatively stable (varying from 8.3 to 8.78), which was suitable for efficient methanogenesis, indicating that the system had sufficient alkalinity to neutralize organic acids coming from the hydrolysis and fermentation stage [23]. After 22 days, a sudden decrease in $\mathrm{pH}$ from 8.68 to 8.3 took place which is attributed to the accumulation of the produced VFA (Volatile Fatty Acid) because of enhancement of the OLR. Accumulation of VFA in the reactor did not sour the reactor. The similar result was reported by Van Haandel and Lettinga about the treatment of domestic wastewater [24].

\section{COD removal efficiency}

The bioreactor performance during the start-up is shown in Figure 4. The reactor was fed with an influent COD of $50 \mathrm{mg} / \mathrm{l}$ and the COD removal efficiency was increased from $40 \%$ to $68 \%$ in the first 21 days. Subsequently, the influent COD concentration was enhanced to $100 \mathrm{mg} / \mathrm{l}$ for the remaining 28 days of the start-up period. As the graph shows, increase in influent COD from $50 \mathrm{mg} / \mathrm{l}$ to $100 \mathrm{mg} / \mathrm{l}$ caused a decline in the COD removal efficiency from $68 \%$ to fewer than $42 \%$ which can be attributed to the fact that the system was put under stress. This phenomenon can be due to the increase in VFAs concentration which is recognizable from sudden decrease in effluent $\mathrm{pH}$ at day 22. Similar observation was reported by other authors $[23,25,26]$. The system recovered shortly and adapted to the new condition with time. Though, in terms of removal efficiency, the increase in influent COD from $50 \mathrm{mg} / \mathrm{l}$ to $100 \mathrm{mg} / \mathrm{l}$ led to an increment in terms of the COD removal efficiency from $68 \%$ to $77 \%$, implying that the sludge was acclimated appropriately to the bilge water. A comparison between Figures 2 and 3 shows a similar trend between effluent $\mathrm{pH}$ and COD removal efficiency which concurs with the results obtained by Zhang et al. [23].

\section{Biogas production rate}

The biogas production rate along the start-up is shown in Figure 5. As the profile shows, the biogas volume rate increased from $0.06 \mathrm{l}$ /day to $0.37 \mathrm{l} /$ day in the first 21 days. The introduction of higher COD to the reactor was caused a sudden decrease in biogas production at day 22. The excess VFA which was produced at this time inhibited the methanogenic bacteria from their efficient performance and as a consequence, the biogas production decreased $[27,28]$. However, the biogas production increased again from day 26 and this indicated that the microorganisms acclimated to the new condition. At the end of the start-up period, the biogas production reached an amount of $0.48 \mathrm{l}$ /day. During the start-up, the biogas production raised like the COD removal efficiency which was in agreement with another author's result [28]. The reason for the increased biogas production is due to proper anaerobic population development [26].

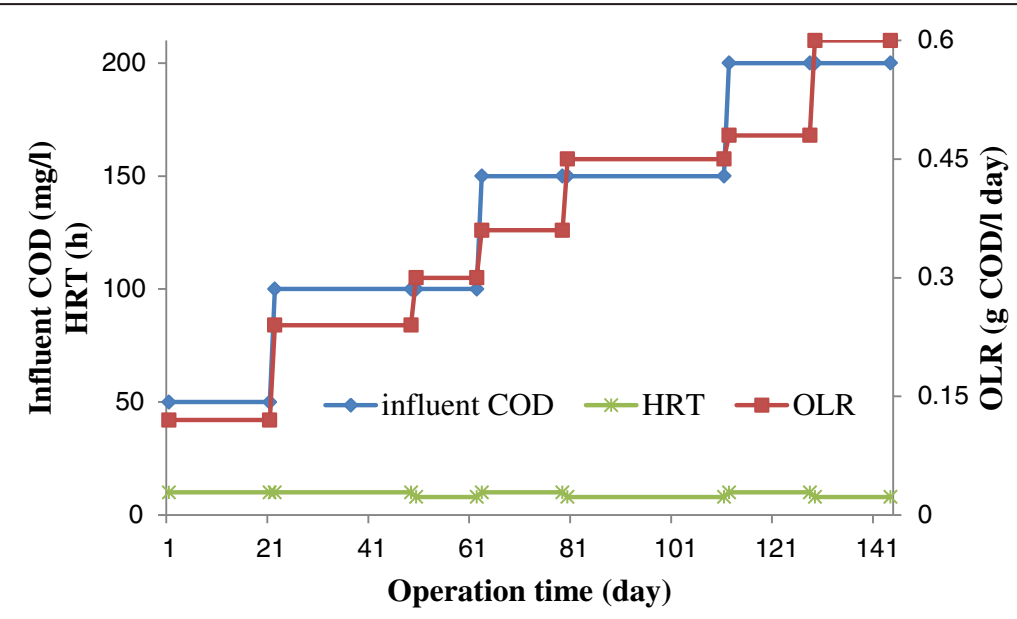

Figure 2 Start-up and operation scheme for UASFF reactor. 


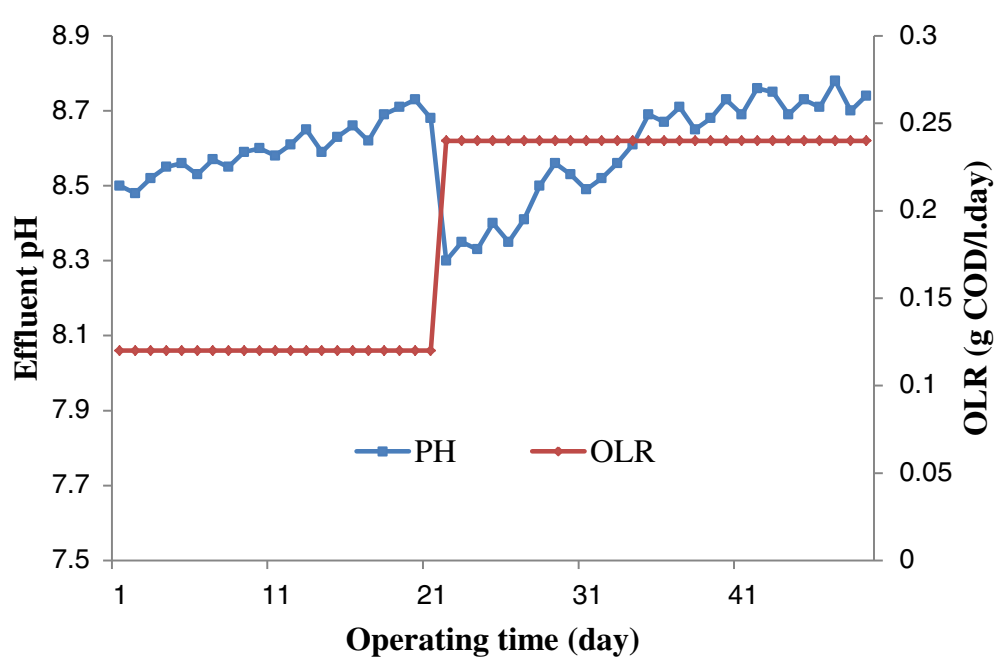

Figure 3 Change of PH during start-up.

The overall performance of the reactor during the startup was satisfactory. It is known that the selection of seed material plays a crucial role in minimizing the time required for start-up duration [26]. In addition, it is clearly understood that the initial immobilization of microorganisms on the surface of the support materials had a key role in progressing the start-up procedure.

\section{Later operation stage}

After a 49-days startup period, the reactor was operated at HRTs of $10 \mathrm{~h}$ and $8 \mathrm{~h}$ with three different influent COD concentrations (from $100 \mathrm{mg} / \mathrm{l}$ to $200 \mathrm{mg} / \mathrm{l}$ ) to evaluate the effect of low organic loadings on the reactor performance.
$\mathrm{pH}$

Figure 6 shows the variation of effluent $\mathrm{pH}$ during the operation. As it shows, the $\mathrm{pH}$ of the treated wastewater was in the range of 8.04-8.61 which is indicative of the buffering capacity of the reactor. There was a sudden decrease in pH from 8.52 at the day of 96 to 8.1 at the day of 111 because at this stage of the operation, the effect of the nutrient was tested. For testing this effect, from the day of 96 to 101, the addition of the nutrient was ceased and after that the new nutrient, $\mathrm{NH}_{4} \mathrm{Cl}$, was added to the reactor till the day of 111. Decrease in $\mathrm{pH}$ in this period of the operation proved that more VFA was accumulated in the reactor due to the lower activity of the methanogenic bacteria which was responsible for

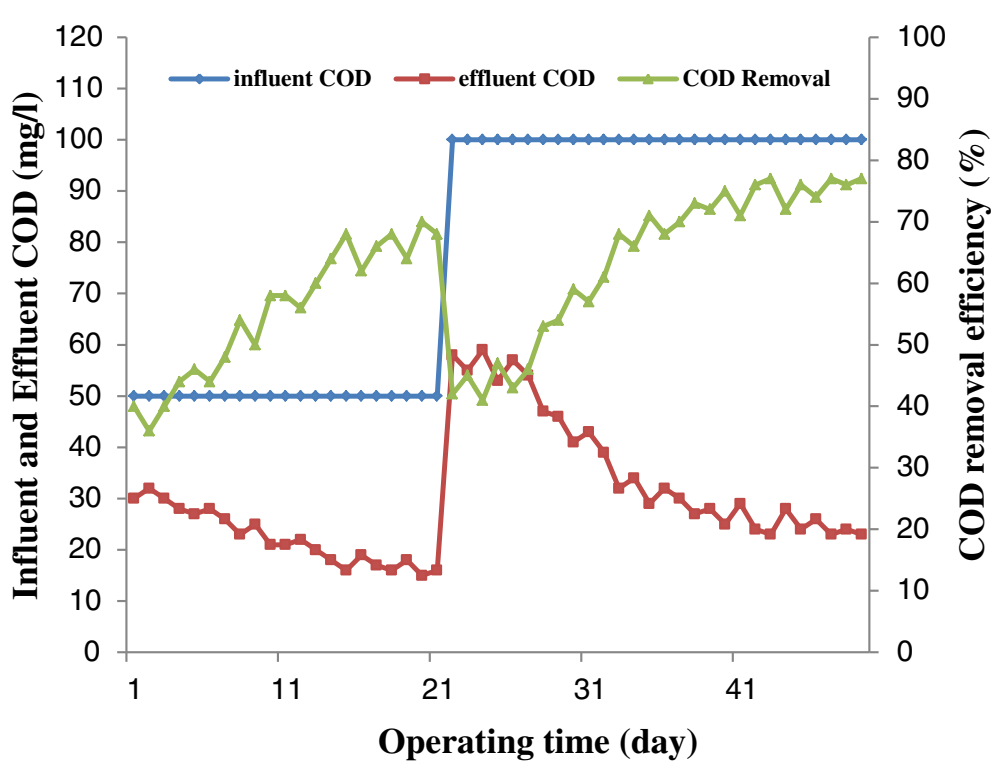

Figure 4 Bioreactor performance during start-up period. 


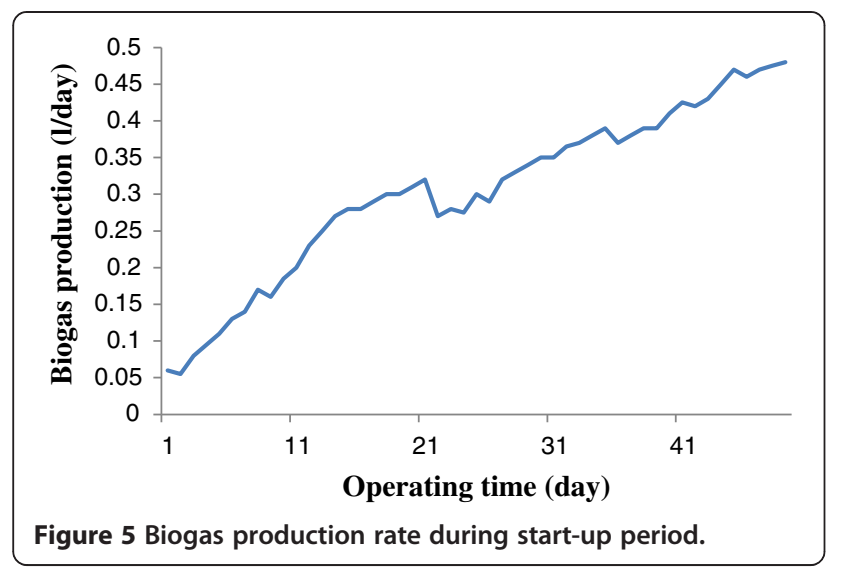

consuming of the VFA. However, the reactor recovered itself because of introducing $\mathrm{MgNO}_{3}$ as the nutrient to the reactor and $\mathrm{pH}$ increased again which is indicative of the increase in methanogenic bacteria functionality.

\section{COD and TSS removal efficiencies}

The performance of UASFF reactor based on COD and TSS removal efficiencies during the operation period is shown in Figure 7 and Figure 8, respectively. As illustrated in the Figure 7, the COD removal efficiency went through an increasing trend from a low amount of 59\% to a maximum of $77 \%$ during the first 46 days except at the beginning of each OLR increment, there was a corresponding decrease in COD removal efficiency but the system recovered shortly and adapted to the new conditions with time like the start-up period $[14,26]$. As Figure 8 illustrates, the influent TSS concentration is unstable because of the poor agitation that was provided in feed tank. As the graph shows, the effluent TSS concentration was very low which is indicative of the good performance of the reactor in eliminating the suspended solids. As it was mentioned before, the effect of the nutrient on the performance of the reactor was tested during the days of 96 to 111 . According to Figure 7, the COD removal efficiency decreased from $77 \%$ to $42 \%$ during the days 96 to 101,the period that the addition of $\mathrm{MgNO}_{3}$ was ceased to the reactor. After that, by addition of new nutrient $\left(\mathrm{NH}_{4} \mathrm{Cl}\right)$ to the reactor, the COD removal efficiency increased a little and reached an amount of $50 \%$ at day 111 . The obtained data demonstrated that $\mathrm{MgNO}_{3}$ was a better choice than $\mathrm{NH}_{4} \mathrm{Cl}$ in the present study. Therefore, $\mathrm{MgNO}_{3}$ was introduced to the reactor again from day 111. Although the COD removal efficiency decreased considerably during the days of 96 to 111, the TSS removal efficiency was still as high as the other days of the operation (see Figure 8). For instance at day 98, the COD removal efficiency declined to the amount of $40 \%$ while the TSS removal efficiency was $97 \%$. This phenomenon indicates that most of the COD removal during this study was due to the reduction of the soluble COD and not the suspended COD. By increasing the COD influent and introduction of $\mathrm{MgNO}_{3}$ as the nutrient to the reactor at the day of 111, the COD removal efficiency raised again and it reached an amount of the $75 \%$ at the end of the study. The obtained result is comparable with the COD removal efficiency achieved by Sun et al. in which they reached the percentages of $59 \%$ in treatment of synthetic bilge water by using an aerobic moving bed bio-reactor (MBBR) [29]. In addition, the reactor achieved TSS removal efficiency of 99\% at the end of the experiment which was a noticeable result. The good performance of the reactor in the eliminating of the TSS content of the wastewater during the operation suggests that most proportion of the TSS removal is due to the entrapment and adsorption of the suspended solids at sludge bed and fixed film [30]. The TSS removal efficiency throughout the experiment did not differ significantly which is in agreement with Ligero et al. results who reported the TSS removal efficiency of

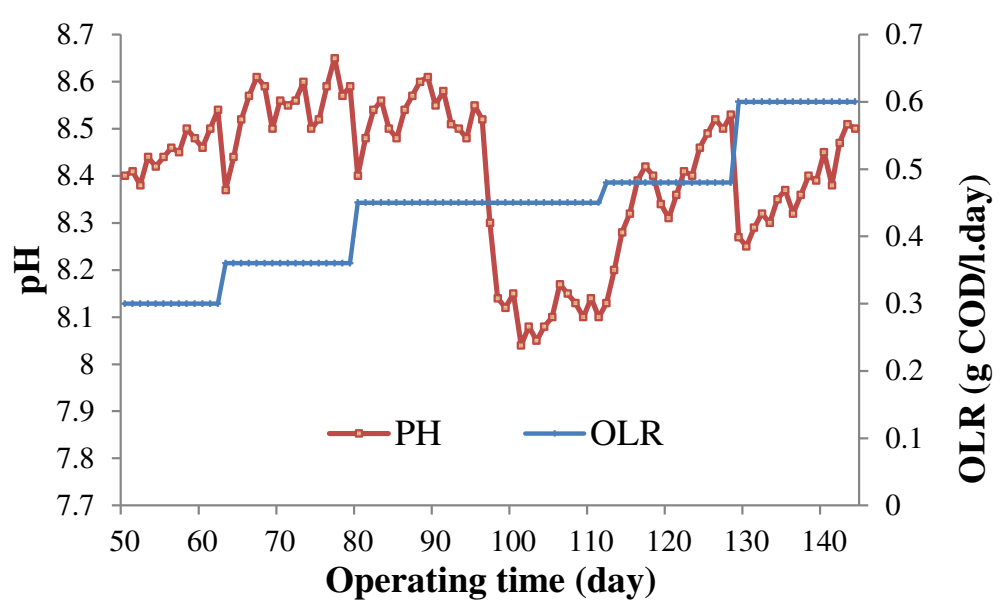

Figure 6 Change of $\mathrm{pH}$ during later operation. 


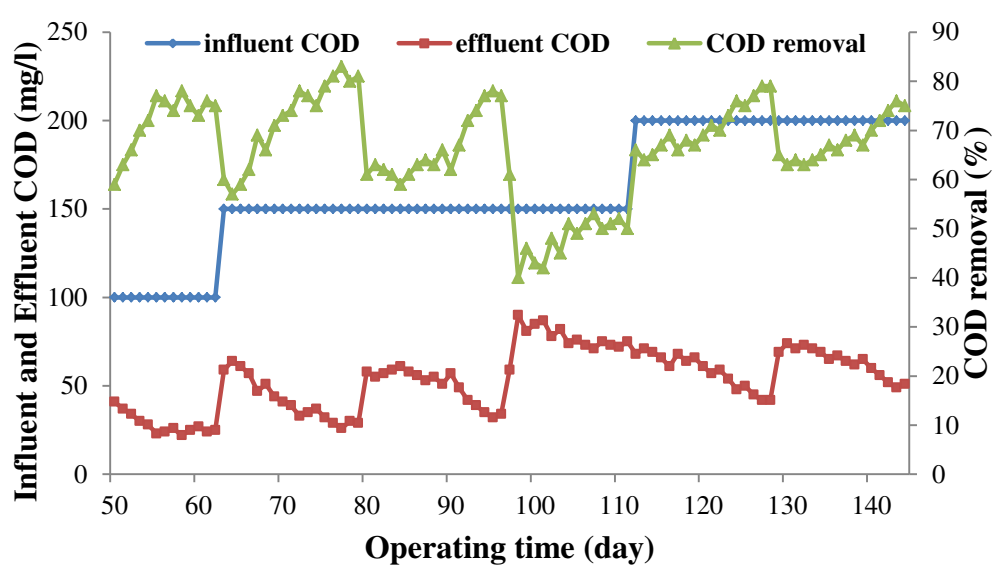

Figure 7 Bioreactor performance during the later operation stage.

an UASB reactor for all values of HRT was not very different [31].

\section{Biogas production rate}

As Figure 9 shows, the biogas production rate increased from $0.52 \mathrm{l} /$ day at the day of 50 to $0.85 \mathrm{l} /$ day at the day of 96. Lettinga reported that the reduction of BOD and COD contributed to the gas production [32]. One can see in Figure 9, the biogas production decreased from $0.85 \mathrm{l} /$ day at the day of 96 to $0.41 \mathrm{l} /$ day at day of 101 (without nutrient addition) and then it reached to the amount of 0.53 at the day of 111 (with addition of $\mathrm{NH}_{4} \mathrm{Cl}$ as the nutrient) which can explain that the activity of methanogenic bacteria decreased at this stage of the operation. By increasing the influent COD and the addition of $\mathrm{MgNO}_{3}$ as the nutrient at the day of 111, the biogas production increased again and it continued to the amount of $0.93 \mathrm{l} /$ day at the end of the study.

\section{Oil content}

The reduction of oil content of the wastewater at the end of start-up and operation of the reactor is shown in
Figure 10. Presence of oil in wastewaters leads to the accumulation of it on the surface of the sludge which causes foaming and scum formation which eventually lowers the digestion efficiency [10]. There was no sign of foam and scum in the reactor which was indicative of the good performance of the reactor. As Figure 10 shows, either at the end of the start-up or at the end of the operation, the oil effluent concentration was below $15 \mathrm{mg} / \mathrm{l}$ which is IMO standard level for discharging the wastewater from ships [1]. The obtained result was so promising in comparison with the outcome of the Sun et al. [29]. They reported that the effluent oil content from the MBBR at the HRT of $8 \mathrm{~h}$ was about $30 \mathrm{mg} / \mathrm{l}$ which was about double times higher than the standard level of discharging [29].

\section{Sludge}

The TSS concentration of the sludge in the reactor increased from $16.5 \mathrm{~g} / \mathrm{l}$ at the beginning of the start-up to $67 \mathrm{~g} / \mathrm{l}$ at the end of the study. This sludge production in the reactor may be attributed to (1) flocculation and entrapment of the non-biodegradable influent TSS, forming

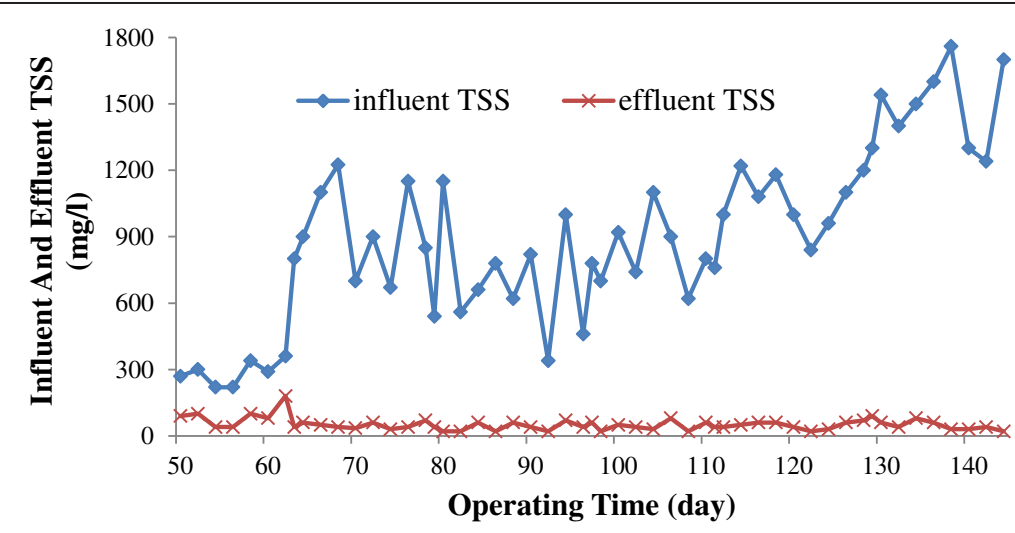

Figure 8 TSS removal during operation. 


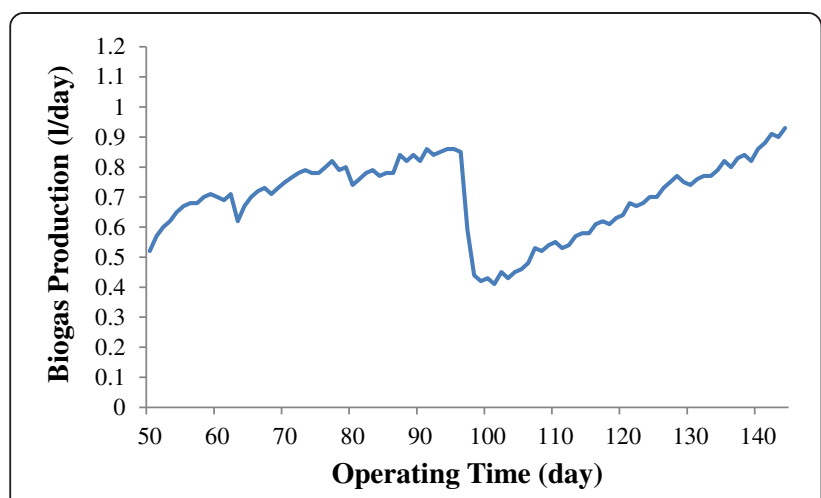

Figure 9 Biogas production during later stage.

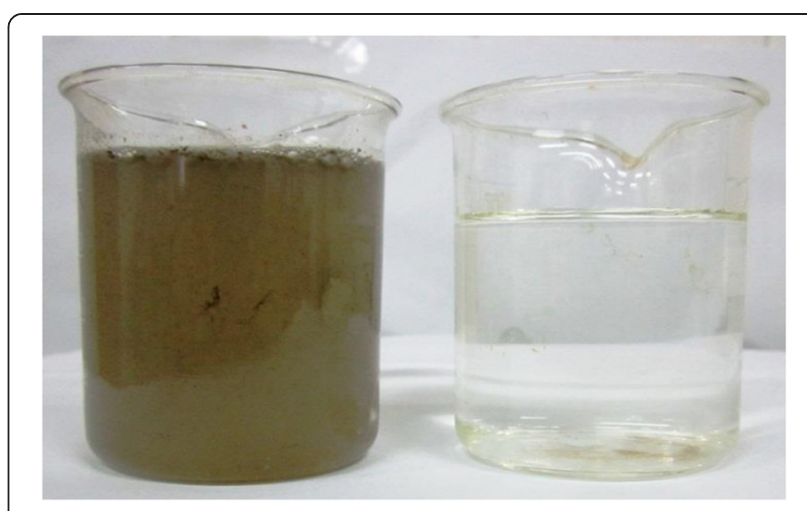

Figure 11 Influent and effluent of the reactor at the end of the operation.

\section{Conclusions}

In this study, anaerobic treatment of dilute bilge water was performed by using UASFF reactor at ambient temperature. After a good resulted immobilization of sludge in the support materials and start-up period, the COD and TSS removal efficiencies reached the amounts of $75 \%$ and $99 \%$ at the end of the operation, respectively. The results showed that the sludge blanket acted as a filter for removing the suspended solids from the wastewater and the major proportion of COD removal was due to the soluble and not suspended COD. The biogas production rate reached an amount of $0.93 \mathrm{l} /$ day at the end of the experiment and effluent oil concentration is remarkably below the standard amount which has been set by the IMO (15 ppm). The good performance of the bioreactor on appearance of the wastewater can be considered as another advantage of this type of the UASFF reactor. The immobilization of the biomass in the support materials had an important role in reducing the influent COD because they created a good media for methanogenic bacteria on their surface. According to the obtained results, it can be concluded that the UASFF reactor is a very promising option for the treatment of the low-strength bilge water, produced from the ships in Caspian Sea, at the ambient temperatures for implementation on the ships in a large scale.

\footnotetext{
Competing interests

The authors declare that they have no competing interests.
}

\section{Authors' contributions}

SME participated in fabricated of the set up plant and contributed to obtained data. MR participated in the fabrication of set up, carried out the experiments and optimization and drafted the manuscript. MH participated in modeling process and helped to draft manuscript. BK participated in the experiments and helped to draft manuscript. All authors have contribution in this research Also all of them read and approved the final format of this manuscript.

\section{Acknowledgments}

The authors wish to acknowledge Biofuel \& Renewable Energy Research Center, Noshirvani University of Technology (Babol, Iran) for the facilities provided to accomplish the present research. 


\section{Author details}

${ }^{1}$ Department of Chemical Engineering, Semnan University, Semnan, Iran. 2Department of Chemical Engineering, Babol University of Technology, Babol, Iran.

Received: 9 July 2014 Accepted: 9 March 2015

Published online: 20 March 2015

\section{References}

1. MARPOL:International Convention for the Prevention of Pollution from Ships, 1973, as modified by the protocol of 1978 relating thereto (MARPOL 73/78). in: (IMO) I.M.O., ed; 1973

2. Ghidossi R, Veyret D, Scotto JL, Jalabert T, Moulin P. Ferry oily wastewater treatment. Sep Purif Technol. 2009;64:296-303.

3. Peng $\mathrm{H}$, Tremblay AY, Veinot DE. The use of backflushed coalescing microfilteration as pretreatment for the ultrafilteration of bilge water. Desalination. 2005;181:109-20.

4. Korbahti BK, Artut K. Electrochemical oil/water demulisification and purification of bilge water using Pt/lr electrodes. Desalination. 2010;258:219-28.

5. Rincon GJ, La Motta EJ. Simultaneous removal of oil and grease, and heavy metals from artificial bilge water using electrocoagulation/flotation. J Environ Manage. 2014;144:42-50.

6. Karakulski K, Morawski WA, Grzechulska J. Purification of bilge water by hybrid ultrafiltration and photocatalytic processes. Sep Purif Technol. 1998;14:163-73.

7. Benito JM, Sanchez MJ, Pena P, Rodriguez MA. Development of a new high porosity ceramic membrane for the treatment of bilge water. Desalination. 2007;214:91-101.

8. Weiland P. Biogas production: current state and perspectives. Appl Microbiol Biotechnol. 2010;85:849-60.

9. Kivaisi AK. The potential for constructed wetlands for wastewater treatment and reuse in developing countries: a review. Ecol Eng. 2001;16:545-60.

10. Tchobanoglous G, Burton FL, Stensel HD. Wastewater Engineering: Treatment and Reuse. New York: McGraw-Hill Education; 2003.

11. Liu Y, Tay JH. State of the art of biogranulation technology for wastewater treatment. Biotechnol Adv. 2004;22:533-63.

12. Goodwin JAS, Finlayson JM, Low EW. A further study of the anaerobic biotreatment of malt whisky distillery pot ale using an UASB system. Bioresour Technol. 2001;78:155-60.

13. Sabry T. Application of the UASB inoculated with flocculent and granular sludge in treating sewage at different hydraulic shock loads. Bioresour Technol. 2008;99:4073-7.

14. Kumar A, Yadav AK, Sreekrishnan TR, Satya S, Kaushik CP. Treatment of low strength industrial cluster wastewater by anaerobic hybrid reactor. Bioresour Technol. 2008;99:3123-9.

15. Chan YJ, Chong MF, Law CL, Hassell DG. A review on anaerobic-aerobic treatment of industrial and municipal wastewater. Cheml Eng J. 2009;155:1-18.

16. Aiyuk S, Amoako J, Raskin L, van Haandel A, Verstraete W. Removal of carbon and nutrients from domestic wastewater using a low investment, integrated treatment concept. Water Res. 2004;38:3031-42.

17. Gomec CY. High-rate anaerobic treatment of domestic wastewater at ambient operating temperatures: A review on benefits and drawbacks J Environ Sci Health A Tox Hazard Subst Environ Eng. 2010:45:1169-84.

18. Leitao RC, Santaellla ST, van Haandel AC, Zeeman G, Lettinga G. The effect of operational conditions on the hydrodynamic characteristics of the sludge bed in UASB reactors. Water Sci Technol. 2011;64:1935-41.

19. DR/890:colorimeter, Procedures Manual, Method 8000. in: Hach Company L., CO, ed; 2009

20. APHA. Standard methods for the examination of Water and Wastewater. Washington, DC: American Public Health Association/American Water Work Association/Water Environmental Federation; 2008.

21. Zaiat M, Cabral AKA, Foresti E. Horizontal-flow anaerobic immobilized sludge reactor for wastewater treatment: conception and performance evaluation. Revista Brasileira de Engenharia. 1994;11:33-42

22. Sunil Kumar G, Gupta SK, Singh G. Biodegradation of distillery spent wash in anaerobic hybrid reactor. Water Res. 2007;41:721-30.

23. Zhang Y, Yan L, Chi L, Long X, Mei Z, Zhang Z. Startup and operation of anaerobic EGSB reactor treating palm oil mill effluent. J Environ Sci. 2008;20:658-63.

24. Van Haandel AC, Lettinga G. Anaerobic sewage treatment- a practical guide for regions with a hot climate. England: John Wiley \& Sons; 1994.
25. Najafpour GD, Zinatizadeh AAL, Mohamed AR, Hasnain Isa M, Nasrollahzadeh $H$. High-rate anaerobic digestion of palm oil mill effluent in an upflow anaerobic sludge-fixed film bioreactor. Process Biochem. 2006;41:370-9.

26. Selvamurugan $M$, Doraisamy $P$, Maheswari $M$. An integrated treatment system for coffee processing wastewater using anaerobic and aerobic process. Ecol Eng. 2010;36:1686-90.

27. Buyukkamaci N, Filibeli A. Volatile fatty acid formation in an anaerobic hybrid reactor. Process Biochem. 2004;39:1491-4.

28. Chan YJ, Chong MF, Law CL. An integrated anaerobic-aerobic bioreactor (IAAB) for the treatment of palm oil mill effluent (POME): Start-up and steady state performance. Process Biochem. 2012;47:485-95.

29. Sun C, Leiknes T, Weitzenbock J, Thorstensen B. Development of an integrated shipboard wastewater treatment system using biofilm-MBR. Sep Purif Technol. 2010;75:22-31.

30. Tawfik A, Sobhey M, Badawy M. Treatment of a combined dairy and domestic wastewater in an up-flow anaerobic sludge blanket (UASB) reactor followed by activated sludge (AS system). Desalination. 2008:227:167-77.

31. Ligero $P$, de Vega A, Soto M. Influence of HRT (hydraulic retention time) and SRT (solid retention time) on the hydrolytic pre-treatment of urban wastewater. Water Sci Technol. 2001;44:7-14.

32. Lettinga $G$. Anaerobic digestion and wastewater treatment systems. Antonie Van Leeuwenhoek. 1995:67:3-28.

33. Nadais H, Capela I, Arroja L, Duarte A. Optimum cycle time for intermittent UASB reactors treating dairy wastewater. Water Res. 2005:39:1511-8.

34. Álvarez JA, Ruíz I, Soto M. Anaerobic digesters as a pretreatment for constructed wetlands. Ecol Eng. 2008;33:54-67.

35. Green M, Shaul N, Beliavski M, Sabbah I, Ghattas B, Tarre S. Minimizing land requirement and evaporation in small wastewater treatment systems. Ecol Eng. 2006;26:266-71.

36. Ruiz I, Díaz MA, Crujeiras B, García J, Soto M. Solids hydrolysis and accumulation in a hybrid anaerobic digester-constructed wetlands system. Ecol Eng. 2010;36:1007-16.

37. Aiyuk S, Verstraete W. Sedimentological evolution in an UASB treating SYNTHES, a new representative synthetic sewage, at low loading rates. Bioresour Technol. 2004:93:269-78.

38. Aiyuk S, Xu H, van Haandel A, Verstraete W, Verstraete W. Removal of ammonium nitrogen from pretreated domestic sewage using a natural ion exchanger. Environ Technol. 2004;25:1321-30.

\section{Submit your next manuscript to BioMed Central and take full advantage of:}

- Convenient online submission

- Thorough peer review

- No space constraints or color figure charges

- Immediate publication on acceptance

- Inclusion in PubMed, CAS, Scopus and Google Scholar

- Research which is freely available for redistribution

Submit your manuscript at www.biomedcentral.com/submit
C) Biomed Central 